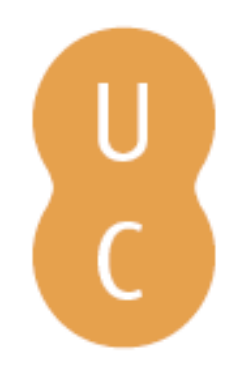

\title{
nommalina
}

\section{Host residents' perceptions towards a mega event: the case of the Athens 2004 Olympic Games}
Autor(es):
Lykoudi, Dimitra Margieta; Zouni, Georgia
Publicado por: Imprensa da Universidade de Coimbra
URL
persistente:
URI:http://hdl.handle.net/10316.2/37377
DOI:
DOI:http://dx.doi.org/10.14195/978-989-26-0754-2_16
Accessed : $\quad$ 26-Apr-2023 09:30:24

A navegação consulta e descarregamento dos títulos inseridos nas Bibliotecas Digitais UC Digitalis, UC Pombalina e UC Impactum, pressupõem a aceitação plena e sem reservas dos Termos e Condições de Uso destas Bibliotecas Digitais, disponíveis em https://digitalis.uc.pt/pt-pt/termos.

Conforme exposto nos referidos Termos e Condições de Uso, o descarregamento de títulos de acesso restrito requer uma licença válida de autorização devendo o utilizador aceder ao(s) documento(s) a partir de um endereço de IP da instituição detentora da supramencionada licença.

Ao utilizador é apenas permitido o descarregamento para uso pessoal, pelo que o emprego do(s) título(s) descarregado(s) para outro fim, designadamente comercial, carece de autorização do respetivo autor ou editor da obra.

Na medida em que todas as obras da UC Digitalis se encontram protegidas pelo Código do Direito de Autor e Direitos Conexos e demais legislação aplicável, toda a cópia, parcial ou total, deste documento, nos casos em que é legalmente admitida, deverá conter ou fazer-se acompanhar por este aviso. 
DIMITRA MARGIETA LYKOUDI

Tilburg University, the Netherlands

D.M.Lykoudi@uvt.nl

\section{GEORGIA ZOUNI}

University of Piraeus, Greece

gzouni@unipi.gr

\section{HOST RESIDENTS, PERCEPTIONS TOWARDS}

\section{A MEgA EVENT: THE CASE OF THE}

\section{ATHENS 2004 OLYMPIC GAMES}

\section{Introduction}

Modern society's great spectacles can be called mega-events. The Olympic Games are probably the world's largest mega event, which can bring both benefits and costs to the host country/ community. Although mega-events are mainly seen in economic terms, in almost all cases they have a significant social effect (Jones, 2001). Despite the fact that the economic impacts of mega-events on host city and country are of utmost importance for both public and private institutions as well as for individuals, resident's more general views and perceptions of such events may add great value to the research field of mega-events. In Tourism Marketing and Event Management Literatures, the investigation of demographic characteristics is of utmost importance. In this study, we examine how the demographic profile of host residents and their perceptions about economic, cultural and environmental Olympic Games impacts influence their perceived overall satisfaction about the Olympic Games. This is the first attempt in Olympic Games literature to investigate such a gap. 


\section{Literature Review}

In the Olympics much more than pure sport are celebrated. Various stakeholders see the Olympic Games as a business/marketing opportunity, a media show, a tourism product/ service, a catalyst for social and urban development, a country image booster, an inspiration and motivation for young people, and a force for peace and fair play. The benefits and the costs of the Olympics are not tightly linked only with the sports field. The added non-sporting roles that are linked with the Olympic Games (such as tourism and marketing roles), may make them more attractive and unique. Within the event tourism context, in which sport events are one of the fastest growing segments, most of the literature has focused on the evaluation of economic benefits (Gelan 2003; Kasimati 2003) and ignored benefits that may stem from the social, cultural, and environmental impacts of such events, as well as local community perceptions towards these impacts (Zhou \& Ap, 2009). Hence, it is crucial to examine host communities' perceptions towards the Olympic Games after the event is staged, so that organizers can apply appropriate future strategies to gain maximum support, value and sustainable advantage, and to avoid, learn and become more efficient for future Mega events.

\subsection{Residents' Demographic Characteristics Investigation}

Events have become an increasingly significant component of destination marketing and they are being used to increase visitation, reduce the seasonality of tourist flow, improve a destination's position in the market, and foster destination development (Kim \& Chalip, 2004). The reason for examining demographic characteristics of residents lies on the notion that demographic segmentation is the most common approach to market segmentation for destination marketing (Tkaczynski, Rundle - Thiele, \& Beaumont, 2009) and event management (Tkaczynski \& Rundle - Thiele, 2010) .Demographics are directly observable (Scott \& Parfitt, 2004) and hence more able to guide managerial decision making. According to Tka- 
czynski, et al. (2009) "demographic characteristics are likely to continue to play an important role in managerial decision making". Generally, sociodemographic variables have been considered as quite usable, since they are easy to assess (Lawson, 1995) and inexpensive, while segments based on demographics are easy to form (Moriarty \& Reibstein, 1986; Bonoma \& Shapiro, 1983; Griffith \& Pol, 1994) and measure (Brayley, 1993; Bowen, 1998). The demographic and psychographic segmentation base is the most popular segmentation approach in the field of events (Tkaczynski \& Rundle-Thiele, 2010). Based on all the above, we hypothesize that the demographic characteristics of host community (age, gender, educational level, region of residence) influence residents' overall satisfaction towards the 2004 Olympic Games and that the impact of the demographics on overall satisfaction is mediated by perceptions about the opening and closing ceremony, the environmental as well as the economic impacts of the Olympics 2004.

\subsection{Cultural, economic and environmental impacts \& Residents' overall satisfaction}

The results of several studies suggest that the host community's perceptions of the total impact (here host residents' overall satisfaction) is affected by perceived impact of several costs and benefit factors on the host community such as economic, environmental, cultural, and social (Yoon et al., 2001). Mega-events can be viewed as large-scale tourism products and integral to tourism development and marketing plans (Getz, 1989). Hence, we expect that perceived cultural, economic and environmental impacts will influence residents' overall satisfaction (total impact). Many scholars (Spilling 1996, Yoon 2001, Essex \& Chalkley 1998, Tomlinson 1996) have argued that these factors have a major impact on host community. So, we hypothesize that the perceived economic, cultural and environmental impacts of the Olympic Games influence host residents' overall satisfaction.

In this paper, we want to examine how the demographic profile of host residents influences their overall satisfaction. This study is the first 
in Olympic Games literature to investigate such a gap. Host residents' overall satisfaction towards a mega event has not been examined before. Social exchange theory in the mega events context could suggest that local residents are likely to participate in exchange as long as the perceived benefits (support and endorsement; thus satisfaction) of the Olympic Games exceed the perceived costs of Games (disapproval, disappointment and thus dissatisfaction). Host residents' overall satisfaction can be seen as a function of social tangible and intangible resources exchange. The ultimate outcome variable of our model is a function of the benefit-cost assessment of the Olympic Games impacts. Social exchange theory can explain the overall satisfaction from the Olympic Games from the willingness of people to enter into a social resource exchange.

\section{Research Methods}

Structured survey questionnaire was used for this study. Many of the items were in accordance with Fredline's and Faulkner's (2000) work. The Independent variables of our model are the demographic characteristics of the citizens of Athens, i.e. gender, age, educational level and region of residence. The perceived Olympic Games mediating impacts by host residents consisted of four items, embodying both positive and negative aspects of the Olympic Games. These items were based on the work of Fredline and Faulkner (2000). A five-point Likert scale was used as the response format for all four impact items with assigned values ranging from 1 "not at all satisfied" to 5 "very satisfied" for the opening and closing ceremony, from 1 "not at all important" to 5 "very important" for the environmental protection and preservation before, during and after the Olympic Games, and from 1 "very negative" to 5 "very positive", for the economic impact of the Olympic Games. Host residents' overall satisfaction from the Olympic Games 2004, the ultimate outcome variable, is measured by a five-point Likert scale. The values range from 1 "not at all satisfied" to 5 "very satisfied". The objects of this study were chosen randomly from the approximately five million residents of the six urban 
districts of Athens. The data were collected in March and April 2005. The sample size consists of 356 individuals.

\section{Research Approach}

Path analysis -the original (SEM) technique- was adopted to test our model. Our Research variables were tested with an AMOS 18 procedure and the maximum likelihood (ML) method (see Anderson \& Gerbing, 1988). All nine variables are categorical and measured via Likert scales, with 5 or more categories, so they can be treated as continuous, except for gender. For the "region of residence" variable, we made dummy variables. Three types of overall model fit measures were utilized in this study: absolute, incremental and parsimonious fit measures (see Kline, 2005).

Errors of mediators and outcome variable are omitted in the graphical representations, as well as the covariances among the demographic variables. The assessment of the initial theoretical proposed model reveals that the model does not fit the data adequately, from both statistical and descriptive point of view. Probability level equals zero, so from a statistical point of view, the model is rejected at both 5\% and 1\% probability levels (CMIN=206.164, $\mathrm{p}=0.000$ ). Furthermore, from a descriptive point of view, all fit indices are quite low (GFI=0.923, $\mathrm{AGFI}=0.500, \mathrm{TLI}=0.354, \mathrm{RMSEA}=0.206, \mathrm{AIC}=360.164)$, so the model could be modified and improved. The Modification indices suggested two direct paths, which were initially not hypothesized, one from the "opening ceremony" to the "closing ceremony" and one from the "opening ceremony" to the "environmental impact". Accordingly, the new paths were added to the model. In addition, apart from the examination of the modifications indices, we inspected visually the matrix of standardized residuals and the Regression weights table in order to modify further our model. Based on all previous modification techniques, we simplified our model by setting the insignificant Regression coefficients equal to zero one by one. The addition of the new paths and the removal of the insignificant coefficients improved the initial theoretical model substantially. We came up with our final revised model which fits the data well. The final revised 
model is acceptable from a statistical point of view at both probability levels (p-value $=0.065)$. From a descriptive point of view, the model is also acceptable and fits the data well (GFI=0.99, AFGI=0.942, TLI=0.946, RMSEA=0.042, $\mathrm{AIC}=174.522$ ). In addition, all standardized residuals are lower than 3 , in absolute values, thus no further modifications are advisable.

\section{Results}

Demographic characteristics of host residents were proved to be statistically significant predictors ( $C R>2$, in absolute values) of their overall satisfaction. No modifications for direct paths between demographic characteristics and host residents' overall satisfaction were suggested by the analysis. Thus, the relationship between demographic characteristics and overall satisfaction is fully mediated by a number of mediators. People with different demographic characteristics had heterogeneous perceptions regarding the perceived overall satisfaction from the 2004 Olympic Games after the completion of the event. Moreover, host residents' perceptions about the economic impact of the Olympic Games 2004 do not influence their overall satisfaction (rejection of our hypothesis about the perceived economic impact, $\mathrm{CR}=0.522$ ). Our results support our hypotheses that the perceived environmental and cultural impacts of the Olympic Games are significant predictors ( $\mathrm{CR}=3.035, \mathrm{CR}=16.577, \mathrm{CR}=2.001$ respectively) of host residents' overall satisfaction (Critical Ratio values are also depicted on the diagram above).

\section{Discussion}

Our study revealed that people with different demographic characteristics had heterogeneous perceptions regarding the perceived impacts of the 2004 Olympics. Our findings are of particular importance for Tourism Marketing researchers and practitioners, considering both the significance of demographic characteristics for the buying (support for the Olympics) 
behavior of consumers (attendees of events or host residents or both), and the extensive use of those characteristics in tourism market segmentation. Tourism Marketers' misconceptions about how demographic characteristics of individuals affect their overall satisfaction from mega events might have serious impact on the segmentation, planning and delivery of the event (tourism) service and experience.

Olympic ceremonies have not been studied before in the context of Mega events as variables that can influence host residents' overall satisfaction. This is a significant gap in Mega events literature. Organizers and marketers, based on the knowledge and experience of previous mega events ceremonies, can carefully plan mega events shows and design event strategies that would guarantee host residents' support and the success of next Mega events. One reason why host residents' perceptions about the economic impact of the Olympics 2004 do not influence their overall satisfaction could be that the economic impacts of the Olympics had not emerged and were not evident the period of the survey. Although the Games cost the taxpayers of Greece US $\$ 14.6$ billion, the overall satisfaction of citizens was based on their perceptions about the ceremonies and the environment, not on the economic impact. It is obvious that most people were excited with the Olympic Games as "show". This is evident and through a cross tabulation analysis, which reveals that people who were overall satisfied had negative perceptions about the economic impacts of the Olympic Games (56.6\%). Our finding is contradictory with Yoon et al., (2001) findings in tourism context. Furthermore, our study indicates that the perceived environmental impact of the Olympic Games is a significant predictor of host residents' overall satisfaction, which is absolutely in line with Yoon et al., (2001) findings that support a direct relationship between residents' perceptions about the environmental impact and their Support for tourism development (which can be replaced in our context by the support for the Olympic Games and thus the residents' overall satisfaction from the Olympic Games).

Perceived cultural impact (opening ceremony) is found to affect local residents' perceptions for environmental impact. The direct positive effect of cultural impact on environmental perceptions indicates that local resi- 
dents are highly concerned with the positive effects of event organization (internal context of the Olympics) on the environment (external context of the Olympics). Perceived positive impacts of internal environment of the Olympics on the external, such as protection of environment, were likely to increase the level of local residents' overall satisfaction. There is a direct link from residents' perceptions about the internal context to perceptions about the external context of the Olympics. The above findings are consistent with the research findings reported by Chen (2000), who found that urban residents were concerned about social and environmental costs due to tourism development (and thus event development).

\section{Future Research, Limitations \& Conclusion}

More rigorous testing of the model is required with different and bigger samples. This research does not claim to have covered and identified all impacts that resulted from the 2004 Olympics. On the contrary, we included only a very small number of factors that may influence host residents' perceptions. Researchers should further identify and examine other factors that may influence host community perceptions for event development, such as community involvement, perception of national identity and cohesion towards the Olympics, community attachment, and utilization of Olympic Games facilities by residents. Integration of these constructs into the model might help researchers and practitioners further analyze and extend the factors that influence local residents support for mega-event development.

Future studies have to be focused on residents' perceptions before, during and after mega event development, because comparing results of before, during and after the event development provides a better and a wholly integrated picture on the dynamics of residents' perceptions or attitudes toward the event organization and development. Therefore, "it is strongly recommended that future sports mega-event host communities or countries should set an ongoing research program to monitor changes in the residents' attitudes multiple times" (Kim et al., 2006). 
Our survey took place in March and April 2005. Within such a long time frame, residents' perceptions towards the Olympic Games may have changed and longitudinal research that manifests and stresses the entire event process is encouraged in order to provide a more substantial and comprehensive understanding of the events development and their impacts.

The purpose of the present study was to provide an effective event management measurement for determining the perceived host residents' satisfaction towards a mega event. Community's perceptions of the Olympic Games impacts on overall satisfaction were proved to be significant. Those, in turn, are affected by the host residents' background. The challenge for marketers is to identify the means to capitalize on demographics in order to optimize event outcome while minimizing the perception of negative impacts, and then to convert event impacts into satisfaction.

Our study demonstrates that host community's perceptions of environmental and cultural impacts of the Olympic Games were important determinants of host community's overall satisfaction. This suggests that event marketers can use this valuable information in order to gain competitive advantage and value in the market. Internal marketing techniques designed to inform residents of the environmental and cultural benefits they receive from mega events, may be helpful in gaining the host community's support that is necessary for the development, successful operation, and sustainability of mega events. Promotion of positive environmental and cultural benefits of events may alter the opinion of host residents who are opposed to mega events. Furthermore, tourism services providers and event businesses should be sensitive to cultural and environmental issues. Organizers of mega-events should give a great attention to the environmental conservation and preservation programs, which will influence positively community's perceptions about mega-events.

Moreover, the results of this study can be useful to destination tourism marketers, who can segment and target their event market based on the demographic profile of possible event attendees. Tourism planners, policy makers and event managers need to ensure that mega-event development will create more benefits than costs for the community and the environment. In addition, the investigation of the host residents' perceptions, after the 
event, helps event organizers and governing institutions and authorities to identify concerns and benefits after the games so that problems can be promptly and properly avoided for future event policies and benefits can be gained through a more efficient event planning. The examination of host residents' perceptions after the event can be utilized as an evaluation tool of how successfully the event has been implemented and organized. If authorities do not address the problem areas, concerns, and issues that stem from host residents' perceptions about the events, it is possible that local residents may be less willing to support the idea of hosting future mega-events (Kim et al., 2006).

Overall, results provide useful information about which variables influence host residents' behavior, such as overall satisfaction towards a mega event. More specifically, demographic segmentation of individuals is widely used in tourism and event management research and practice and our findings indicate that, in fact demographic characteristics might have a serious impact on individuals' overall satisfaction towards a mega event. In addition, this study can serve to provide practitioners and scholars in the tourism and event management field with applied research in an underserved subject that has major influence on the task of mega event development, the destination marketing and event strategy.

\section{References}

Anderson J.C. \& Gerbing D.W. 1988, Structural Equation Modeling in Practice: A Review and Recommended Two-Step Approach. Psychological Bulletin, Vol. 103, No. 3, pp. 411-423.

Bonoma, T., \& Shapiro, B. 1984, Evaluating Market Segmentation Approaches. Industrial Marketing Management, 13, pp. 257-268.

BOWEN, J.T. 1998, Market segmentation in hospitality research: no longer a sequential process. International Journal of Contemporary Hospitality Management, 10(7), 289-296.

Brayley, R.E. 1993, Psychological Segmentation. In M. Khan, M. Olsen, \& T. Var (Eds.), Encyclopedia of hospitality and tourism (pp. 902-909). New York, VNR. 
Chen, J. S. 2000, An investigation of urban residents' loyalty to tourism. Journal of Hospitality and Tourism Research, 24 (1), 21$\} 35$.

Essex S. and Chalkley B. 1998, Olympic Games: catalyst of urban change, Leisure Studies, 17: 3, pp. 187-206.

Fredline E. and Faulkner B. 2000, Host Community Reactions. A Cluster Analysis. Annals of Tourism Research, 27 (3), pp. 763-784.

Gelan, A. 2003, Local Economic Impacts, the British Open. Annals of Tourism Research, 30 (2): 406-25.

GRIfFITH R. L., \& POL, L. G. 1994, Segmenting Industrial Markets. Industrial Marketing Management, 23, pp. 39-46.

JONES, C. 2001, Mega-events and host-region impacts: Determining the true worth of the 1999 Rugby World Cup. International Journal of Tourism Research, 3 (3), pp. 241-251.

Kasimati, E. 2003, Economic Aspects and the Summer Olympics: A Review of Related Research, International Journal of Tourism Research, 5:433-44.

Kim, N. S., \& ChaliP, L. 2004, Why travel to the FIFA World Cup? Effects of motives, background, interest, and constraints. Tourism Management, 25 (6), 695-707.

KIm, J., Gursoy, D., and LeE, S. 2006, The Impact of the 2002 World Cup on South Korea: Comparisons of Pre and Post-Games. Tourism Management, 27:86-96.

KLINE R.B. 2005, Principles and practice of structural equation modeling $\left(2^{\text {nd }}\right.$ edition). The Guildford Press.

LAWson, R. 1995, Demographic Segmentation. In Witt, S., \& L. Moutinho (Eds.), Tourism Marketing and Management Handbook (pp. 306-315). London: Prentice Hall.

Moriarty, R. T., \& Reibstein, D. J. 1986, Benefit Segmentation in Industrial Markets. Journal of Business Research, 14, 463-486.

ScotT, N., \& PARfitT, N. 2004, Lifestyle segmentation in tourism and leisure: imposing order or finding it? Journal of Quality Assurance in Hospitality and Tourism, 5(2-4), 121-139.

SPILling, Olav R. 1996, Mega event as strategy for regional development. The case of the 1994 Lillehammer Winter Olympics. Entrepreneurship \& Regional Development, 8:4, 321-344.

Tkaczynski A., Rundle-Thiele S.R., 2010, Event segmentation: A review and research agenda. Tourism Management (2010) 1-9. 
Tkaczynski, A., Rundle-Thiele, S.R., \& Beaumont, N. 2009, Segmentation: A tourism stakeholder view. Tourism Management, 30 (2), 169-175.

Tomlinson A. 1996, Olympic spectacle: opening ceremonies and some paradoxes of globalization. Media Culture E Society 1996 18: 583.

Yoon Y., Gursoy D., \& Chen J.S. 2001, Validating a tourism development theory with structural equation modeling. Tourism Management, 22 (4), 363-372.

ZHOU Y. and Ap J. 2009, Residents' Perceptions towards the Impacts of the Beijing 2008 Olympic Games. Journal of Travel Research , 48 (1), 78-91. 
The theoretical proposed model (graphical representation)

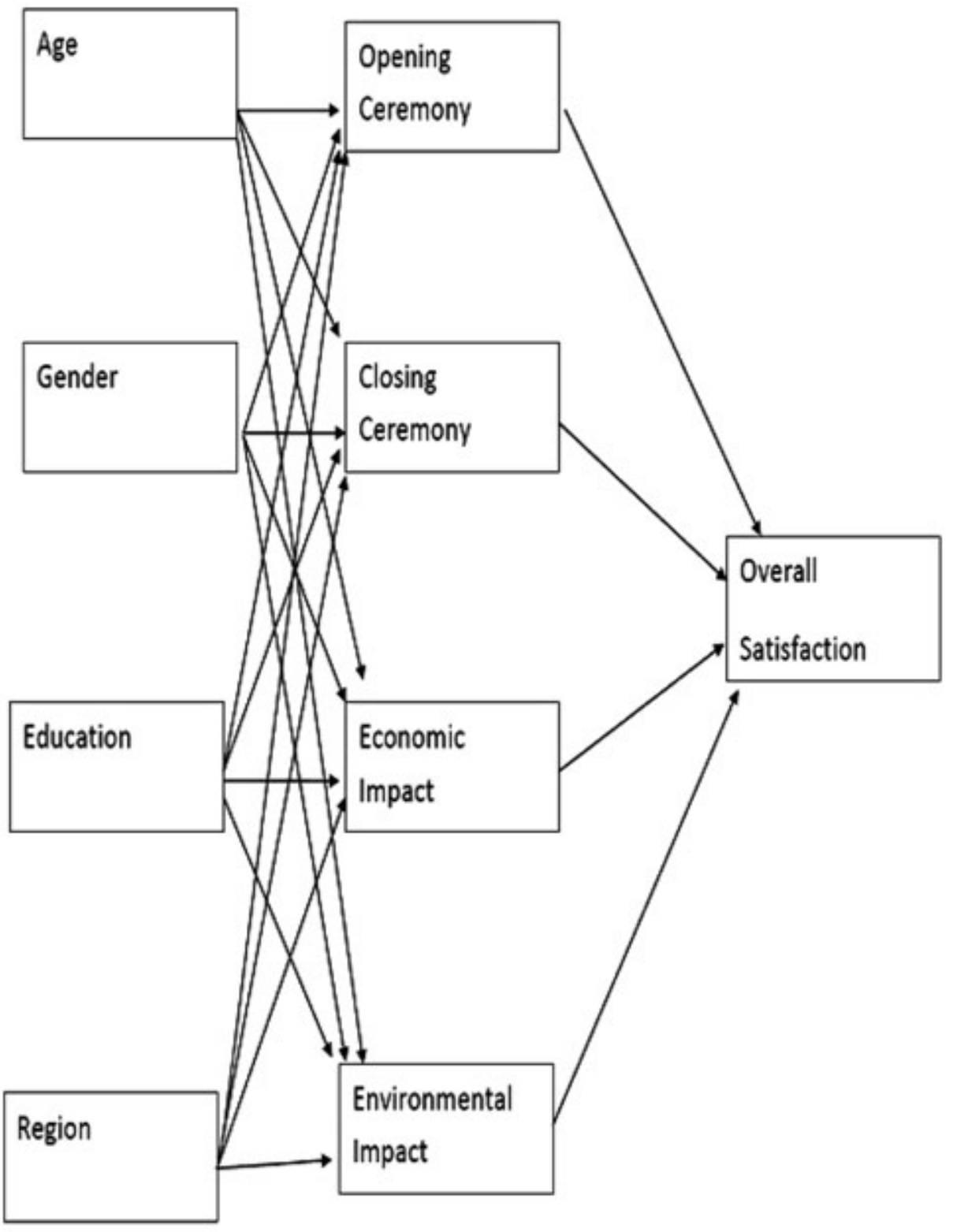

